\title{
Chemical and biological characterization of acid sulphate Kuttanad soils
}

\author{
V. ARYA NATH, B. APARNA AND MANORAMA THAMPATTI
}

Received : 15.07.2016; Revised : 17.10.2016; Accepted : 12.11 .2016

\section{MEMBERS OF RESEARCH FORUM:}

Corresponding author :

V. ARYA NATH, Department of Soil Science and Agricultural Chemistry, College of Agriculture, Vellayani, THIRUVANANTHAPURAM (KERALA) INDIA

Email: krishna6vnt@gamil.com

Co-authors :

B. APARNA AND MANORAMA THAMPATTI, Department of Soil Science and Agricultural Chemistry, College of Agriculture, Vellayani, THIRUVANANTHAPURAM (KERALA) INDIA

\section{Summary}

Kuttanad, the rice bowl of Kerala is a unique agricultural tract lying 0.6 to $2.2 \mathrm{~m}$ below MSL. The soils of the area are highly acidic, saline and high in organic carbon content. Several parts of this delta have subsoil layers containing pyrites which on oxidation produce severe acidity. Hence, the present study was envisaged to characterize the acid sulphate wet land soils of Kuttanad. For the collection of soil samples, stratified random sampling technique was followed. Surface $(0-15 \mathrm{~cm})$ and sub surface $(15-30 \mathrm{~cm})$ soil samples were collected from the identified six soil series viz., Ambalapuzha, Kallara, Purakkad, Thakazhi, Vaikom and Thuravoor. From the study it is inferred that the $\mathrm{pH}$ of the samples varied between 3.0 -4.0 which is typical for acid sulphate soils. Lab incubation studies also revealed that there was a drastic decline in the $\mathrm{pH}$ of the soil with submergence while the EC ranged between $0.1-8 \mathrm{dS} / \mathrm{m}$. With regard to the enzyme assay between the locations, subsurface soil samples collected from the wetlands of Thuravoor reported to have the highest value of $76.1 \mathrm{ppm}$ of urea hydrolysed $\mathrm{g}^{-1}$ of soil hr ${ }^{1}$ for urease and surface samples of Thakazhi had the highest of $105.8 \mu \mathrm{g}$ of p-nitrophenol released $\mathrm{g}^{-1}$ of soil $\mathrm{hr}^{-1}$ for phosphatase. In the case of respiratory activity, which is an indicator of soil microbial biomass, surface samples from Thuravoor recorded the highest followed by Vaikom.

Key words : Acid sulphate soils, Kuttanad, Enzyme studies, Incubation studies

How to cite this article : Nath, V. Arya, Aparna, B. and Thampatti, Manorama (2016). Chemical and biological characterization of acid sulphate Kuttanad soils. Asian J. Soil Sci., 11 (2) : 269-276 : DOI : 10.15740/HAS/AJSS/11.2/269-276. 